\title{
HUBUNGAN LARANGAN MEROKOK DI RUMAH DENGAN KEBERHASILAN BERHENTI MEROKOK
}

\author{
Kadar Ramadhan ${ }^{1}$ \\ ${ }^{1}$ Program Studi Keperawatan Poso, Politeknik Kesehatan Kementerian Kesehatan Palu \\ Email : Kadarlaure@yahoo.com
}

\begin{abstract}
ABSTRAK
Hasil Survei Penggunaan Tembakau Indonesia (GATS) 2011 mengindikasikan bahwa meskipun banyak perokok yang berkeinginan untuk berhenti merokok, namun hanya sedikit yang berhasil berhenti merokok. Penelitian ini bertujuan untuk mempelajari hubungan larangan merokok di rumah dengan keberhasilan berhenti merokok. Desain survei GATS adalah studi potong lintang. Penduduk yang berusia $\geq 15$ tahun keatas sebagai populasi target. Dari 8.305 sampel GATS yang telah dipilih secara stratified cluster sampling 4 tahap, dipilih 1.376 responden yang pernah mencoba berhenti merokok sebagai sampel. Keberhasilan berhenti merokok sebagai variabel dependen. Statistik deskriptif dilaporkan dalam proporsi tertimbang. Analisis multivariabel menggunakan regresi logistik sekaligus melakukan adjustment terhadap beberapa variabel perancu. Hasil analisis menunjukan adanya larangan merokok di rumah meningkatkan odds 2 kali (OR: 2,0; 95\%CI 1,1-3,4) untuk berhasil berhenti merokok dibanding yang tidak ada larangan merokok di rumah. Larangan merokok di rumah dapat meningkatkan keberhasilan dalam berhenti merokok.
\end{abstract}

Kata Kunci $\quad$ : Berhenti Merokok; Larangan Merokok; Rokok; Rumah; Tembakau

\begin{abstract}
The Global Adult Tobacco Survey (GATS) in 2011 indicated that despite the intention of tobacco user to cease smoking, only a few people that succeed to stop the smoking habit. This research aimed to investigate correlation between smoking bans at home and smoking cessation. The GATS design was a cross-sectional study. Resident $\geq 15$ y.o as the target population and as much as 8.305 respondents were recruited by stratified multistage cluster sampling (4 stages) and only 1.376 respondent who had tried to quit smoking were chosen as the sample and being analyzed. The dependent variable was the achievement of smoking cessation. The descriptive statistic was reported in weighted proportions. Logistic regression analysis and adjustment for confounders were applicated. Smoking bans at home increased the odds of smoking cessation achievement by $200 \%$ (OR: 2,0; 95\% CI 1,1-3,4) compared to the inexistence of such rule at home. As a conclusion, smoking bans at home was able to increase the smoking cessation achievement in the stop smoking program.
\end{abstract}

Keywords $\quad$ : Cigarret; Home; Smoking Bans; Smoking Cessation

\section{PENDAHULUAN}

Jumlah perokok aktif di dunia mencapai 1,2 milyar orang ${ }^{1}, 15.2 \%$ dari penduduk dunia saat ini. Menurut WHO, $80 \%$ perokok di dunia berdomisili di negara berkembang ${ }^{2}$. Prevalensi perokok dewasa sebesar $29.5 \%$ di Asia Tenggara, dan Indonesia menempati urutan teratas sebesar $51,1 \%{ }^{3}$. Perilaku merokok penduduk 15 tahun keatas di Indonesia, dari 2007 ke 2013 cenderung meningkat dari 34,2\% tahun 2007 menjadi 36,3\% tahun 2013, sebesar $64,9 \%$ lelaki dan $2,1 \%$ perempuan masih mengkonsumsi rokok tahun 2013. Ditemukan $1,4 \%$ perokok umur $10-14$ tahun, $9,9 \%$ perokok pada kelompok tidak bekerja, dan 32,3\% pada kelompok kuintil indeks kepemilikan terendah, sedangkan rerata jumlah batang rokok yang dikonsumsi adalah sekitar 12,3 batang ${ }^{4}$.

Pada tahun 2010, 38,8\% penduduk semua umur terpajan asap rokok di dalam rumah dimana pajanan pada perempuan $52,9 \%$ lebih tinggi dibanding lelaki yang hanya $24,9 \%$. Angka pajanan tertinggi adalah pada kelompok umur 10-14 tahun sebesar 57,5\% 
Tahun 2013 jumlah ini meningkat menjadi $39 \%$, 54\% pada perempuan dan $24,2 \%$ pada lelaki. Angka pajanan tertinggi pada kelompok umut 5-9 tahun yakni sebesar 57,4\% .

Angka kematian akibat rokok di negera berkembang meningkat hampir empat kali lipat dari 2,1 juta pada tahun 2000 menjadi 6,4 juta pada tahun 2030, sementara di negara maju tren angka kematian akibat konsumsi tembakau justru menurun dari 2,8 juta menjadi 1,6 juta dalam jangka waktu yang sama ${ }^{6}$. Angka kematian di Indonesia terkait tembakau tahun 2013 diperkirakan sebesar 240.618 kasus atau $13,8 \%$ dari total kematian 1.741.691. Jumlah kematian terbanyak disebabkan oleh penyakit stroke, bayi berat lahir rendah, serta kanker trakea, bronkus, dan paru?

Beberapa negara telah menerapkan kebijakan dan undang-undang bebas asap rokok, dengan tujuan untuk melindungi perokok pasif dari asap rokok orang lain, selain itu kebijakan ini dapat memotivasi dan membantu perokok untuk berhenti dan mencegah inisiasi penggunaan tembakau. Pelaksanaan hukum dan kebijakan bebas asap dapat meningkatkan penghentian dan mengurangi prevalensi merokok di kalangan pekerja dan masyarakat umum juga dapat mengurangi inisiasi merokok di kalangan remaja $^{8}$. Kebijakan Kawasan Tanpa Rokok (KTR) di Indonesia merupakan upaya untuk melindungi masyarakat dari paparan asap rokok di tempat umum, yang termasuk dalam salah satu dari 10 indikator Pola Hidup Bersih dan Sehat (PHBS) dalam tatanan rumah tangga adalah tidak merokok dalam rumah untuk melindungi perempuan terutama ibu hamil dan anak dari paparan asap rokok di rumah.

\section{METODE PENELITIAN}

Data yang digunakan dalam penelitian ini adalah Global Adult Tobacco Survey (GATS) Indonesia 2011. Desain survei GATS adalah cross sectional. Target populasi mencakup semua lelaki dan perempuan dewasa di Indonesia yang berusia 15 tahun keatas dengan metode pengambilan sampel stratified cluster sampling 4 tahap. Jumlah sampel GATS adalah 8.305 sedangkan sampel yang dianalisis adalah responden yang pernah mencoba berhenti merokok yakni sebanyak 1.376 responden.

Variabel dependen dalam penelitian ini adalah keberhasilan berhenti merokok, variabel independen adalah larangan merokok di rumah. Variabel perancu terdiri atas: (1) karakteristik responden (umur, jenis kelamin, pendidikan, pekerjaan, daerah, tinggal bersama anggota rumah tangga yang lain, tinggal dengan anak umur $<15$ tahun) (2) konsumsi tembakau bukan rokok, (3) anggota rumah tangga lain yang merokok, (4) pengetahuan tentang bahaya merokok, (5) media tentang informasi utnuk berhenti merokok, dan (6) iklan tentang promosi produk tembakau.

Analisis data dilakukan dengan memperhatikan metode pengambilan sampel, karena tidak semua data GATS digunakan maka dilakukan pembobotan ulang. Statistik deskriptif dilaporkan dalam proporsi tertimbang. Untuk analisis multivariabel menggunakan regresi logistik sekaligus melakukan adjustment dengan variabel perancu. Melaporkan asosiasi antar varibel independen dengan variabel dependen dengan Adjusted OR. 


\section{HASIL PENELITIAN}

Tabel 1. Karakteristik Responden dan Variabel Perancu

\begin{tabular}{|c|c|c|c|c|c|c|}
\hline \multirow{4}{*}{ Variabel Penelitian } & & & \multicolumn{4}{|c|}{ Analisis Bivariat } \\
\hline & \multirow{2}{*}{\multicolumn{2}{|c|}{$\begin{array}{c}\text { Analisis Univariat } \\
\mathrm{n}=1376\end{array}$}} & \multicolumn{4}{|c|}{ Keberhasilan berhenti merokok } \\
\hline & & & \multicolumn{2}{|c|}{ Gagal $(n=821)$} & \multicolumn{2}{|c|}{ Berhasil $(n=555)$} \\
\hline & $\% *$ & $95 \%$ CI* & $\% *$ & $95 \%$ CI* & $\% *$ & $95 \% \mathrm{CI}^{*}$ \\
\hline \multicolumn{7}{|l|}{ Variabel Dependen: } \\
\hline \multicolumn{7}{|l|}{$\begin{array}{l}\text { Keberhasilan berhenti } \\
\text { merokok }\end{array}$} \\
\hline Gagal berhenti & 62,3 & $58,0-66,4$ & & & & \\
\hline Berhasil berhenti & 37,7 & $33,6-42,0$ & & & & \\
\hline \multicolumn{7}{|l|}{ Variabel Independen: } \\
\hline \multicolumn{7}{|c|}{ Larangan merokok di rumah } \\
\hline Tidak Ada & 94,1 & $92,1-95,6$ & 63,8 & $59,53-67,8$ & 36,2 & $32,18-40,5$ \\
\hline Ada & 5,9 & $04,4-07,9$ & 45,6 & $32,99-58,8$ & 54,4 & $41,19-67,0$ \\
\hline
\end{tabular}

Karakteristik responden:

\begin{tabular}{|c|c|c|c|c|c|c|}
\hline \multicolumn{7}{|l|}{ Umur (tahun) } \\
\hline $15-24$ & 23,9 & $21,4-26,6$ & 72,6 & $63,38-80,2$ & 27,4 & $19,83-36,6$ \\
\hline $24-44$ & 45,3 & $43,0-47,6$ & 64,8 & $59,36-69,8$ & 35,2 & $30,22-40,6$ \\
\hline $45-64$ & 23,7 & $22,0-25,3$ & 56,4 & $49,04-63,5$ & 43,6 & $36,53-51,0$ \\
\hline $65+$ & 7,1 & $6,2-08,3$ & 32,4 & $25,21-40,5$ & 67,6 & $59,55-74,8$ \\
\hline \multicolumn{7}{|l|}{ Jenis kelamin } \\
\hline Lelaki & 94,7 & $93,3-95,9$ & 65,1 & $60,52-69,3$ & 34,9 & $30,66-39,5$ \\
\hline Perempuan & 5,3 & $4,2-06,7$ & 32,6 & $24,14-42,3$ & 67,4 & $57,70-75,9$ \\
\hline \multicolumn{7}{|l|}{ Pendidikan } \\
\hline Tidak sekolah & 22,0 & $18,8-25,6$ & 56,0 & $48,5-63,4$ & 44,0 & $36,7-51,5$ \\
\hline Dasar & 47,5 & $44,5-50,4$ & 67,7 & $61,9-72,9$ & 32,3 & $27,1-38,1$ \\
\hline Menengah & 24,3 & $21,5-27,4$ & 61,4 & $54,7-67,7$ & 38,6 & $32,3-45,3$ \\
\hline Tinggi & 6,2 & $5,1-07,6$ & 49,2 & $39,6-66,4$ & 50,8 & $41,1-60,4$ \\
\hline \multicolumn{7}{|l|}{ Pekerjaan } \\
\hline Tidak bekerja & 15,9 & $13,8-18,2$ & 47,5 & $38,0-57,1$ & 52,5 & $42,9-62,0$ \\
\hline Bekerja & 84,1 & $81,8-86,2$ & 65,6 & $60,7-70,1$ & 34,4 & $29,9-39,3$ \\
\hline \multicolumn{7}{|l|}{ Daerah } \\
\hline Perkotaan & 49,4 & $46,8-52,1$ & 61,0 & $55,2-66,6$ & 39,0 & $33,4-44,8$ \\
\hline Pedesaan & 50,6 & $47,9-53,2$ & 63,4 & $57,1-69,3$ & 36,6 & $30,7-42,9$ \\
\hline \multicolumn{7}{|c|}{$\begin{array}{l}\text { Tinggal bersama anggota } \\
\text { rumah tangga yang lain }\end{array}$} \\
\hline Tidak & 2,4 & $01,8-03,1$ & 51,0 & $40,3-61,6$ & 49,0 & $38,4-59,7$ \\
\hline $\mathrm{Ya}$ & 97,6 & $96,9-98,2$ & 62,6 & $58,3-66,8$ & 37,4 & $33,2-41,7$ \\
\hline \multicolumn{7}{|c|}{ Tinggal dengan anak umur } \\
\hline \multicolumn{7}{|c|}{$<15$ tahun } \\
\hline Tidak & 33,0 & $30,7-35,4$ & 56,5 & $49,9-62,9$ & 43,5 & $37,1-50,1$ \\
\hline $\mathrm{Ya}$ & 67,0 & $64,6-69,3$ & 65,0 & $60,3-69,3$ & 35,0 & $30,7-39,7$ \\
\hline \multicolumn{7}{|c|}{ Variabel perancu: } \\
\hline \multicolumn{7}{|c|}{$\begin{array}{l}\text { Konsumsi tembakau bukan } \\
\text { rokok }\end{array}$} \\
\hline Tidak & 97,2 & $96,2-97,9$ & 61,9 & $57,5-66,0$ & 38,1 & $34,0-42,5$ \\
\hline $\mathrm{Ya}$ & 2,8 & $2,1-03,8$ & 79,4 & $58,1-91,4$ & 20,6 & $8,6-41,9$ \\
\hline
\end{tabular}




\begin{tabular}{|c|c|c|c|c|c|c|}
\hline \multirow{4}{*}{ Variabel Penelitian } & \multirow{3}{*}{\multicolumn{2}{|c|}{$\begin{array}{c}\text { Analisis Univariat } \\
\mathrm{n}=1376\end{array}$}} & \multicolumn{4}{|c|}{ Analisis Bivariat } \\
\hline & & & \multicolumn{4}{|c|}{ Keberhasilan berhenti merokok } \\
\hline & & & \multicolumn{2}{|c|}{ Gagal $(n=821)$} & \multicolumn{2}{|c|}{ Berhasil $(n=555)$} \\
\hline & $\% *$ & $95 \%$ CI* & $\% *$ & $95 \% \mathrm{CI}^{*}$ & $\% *$ & $95 \% \mathrm{CI}^{*}$ \\
\hline \multicolumn{7}{|l|}{$\begin{array}{l}\text { Anggota rumah tangga lain } \\
\text { yang merokok }\end{array}$} \\
\hline Ada & 39,8 & $37,0-42,6$ & 63,6 & $57,2-69,6$ & 36,4 & $30,4-42,8$ \\
\hline Tidak ada & 60,2 & $57,4-63,0$ & 61,3 & $56,3-66,2$ & 38,7 & $33,9-43,7$ \\
\hline \multicolumn{7}{|c|}{$\begin{array}{l}\text { Pengetahuan tentang bahaya } \\
\text { merokok }\end{array}$} \\
\hline Kurang & 95,1 & $92,8-96,7$ & 62,6 & $58,2-66,8$ & 37,4 & $33,2-41,8$ \\
\hline Baik & 4,9 & $03,3-07,2$ & 57,7 & $41,3-72,6$ & 42,3 & $27,4-58,8$ \\
\hline \multicolumn{7}{|l|}{$\begin{array}{l}\text { Media tentang informasi } \\
\text { untuk berhenti merokok }\end{array}$} \\
\hline Tidak terpapar & 44,7 & $40,3-49,2$ & 61.5 & $54,6-68,0$ & 38,5 & $32,0-45,4$ \\
\hline Terpapar & 55,3 & $50,8-59,8$ & 62,7 & $58,0-67,2$ & 37,3 & $32,8-42,0$ \\
\hline \multicolumn{7}{|l|}{$\begin{array}{l}\text { Iklan tentang promosi } \\
\text { produk tembakau }\end{array}$} \\
\hline Terpapar & 87,8 & $85,0-90,0$ & 63,7 & $59,4-67,8$ & 36,3 & $32,3-40,6$ \\
\hline Tidak terpapar & 12,2 & $10,0-15,0$ & 52,7 & $39,5-65,6$ & 47,3 & $34,4-60,5$ \\
\hline
\end{tabular}

*) proporsi tertimbang

Tabel 1 menunjukan dari 1376 responden yang pernah mencoba berhenti merokok, hanya $37,3 \%$ yang berhasil berhenti, dan hanya $5,9 \%$ responden yang memiliki aturan larangan merokok di rumah. Dari 37,3\% responden yang berhasil berhenti merokok, lebih dari setengahnya $(54,4 \%)$ menerapkan larangan merokok di rumahnya.

Tabel 2 Hubungan Larangan Merokok di Rumah dengan Keberhasilan Berhenti Merokok

\begin{tabular}{ccccccc}
\hline \multirow{2}{*}{ Keberhasilan berhenti merokok } & \multicolumn{3}{c}{ Crude } & \multicolumn{3}{c}{ Adjusted* $^{*}$} \\
\cline { 2 - 7 } & OR & P value & 95\% CI & OR & P value & 95\%CI OR \\
\hline $\begin{array}{c}\text { Larangan merokok di rumah: } \\
\text { Ada }\end{array}$ & 2,1 & 0,006 & $1,2-3,6$ & 2,0 & 0,019 & $1,1-3,4$ \\
\hline
\end{tabular}

*) Dikontrol dengan variabel karakteristik responden dan variabel perancu

Hasil analisis multivariabel pada tabel 2 menunjukan secara statistik ada hubungan yang sangat signifikan antara larangan merokok di rumah dengan keberhasilan berhenti merokok (OR: 2,0; 95\%CI 1,1-3,4, p<0,01) setelah mengontrol variabel karateristik responden dan beberapa variabel perancu.

\section{PEMBAHASAN}

Hasil penelitian menunjukan bahwa tinggal di rumah dengan larangan merokok berhubungan dengan keberhasilan berhenti merokok dibandingkan dengan tinggal di rumah tanpa larangan merokok. Orang yang tinggal di rumah dengan larangan merokok memiliki odds 2 kali untuk berhasil berhenti merokok dibanding yang tidak ada larangan merokok di rumah. Hal menarik dari penelitian ini adalah proporsi yang berhasil berhenti justru lebih banyak pada yang tidak tinggal bersama anggora rumah tangga yang lain dan tidak tinggal dengan anak. Ini mungkin karena tujuan larangan merokok di rumah murni untuk menekan kebiasaan merokok, bukan untuk menghindarkan anak dari paparan asap rokok.

Dalam teori Health Belief Model, salah satu variabel kuncinya adalah perceived suspectibility. Seseorang merasa yakin dirinya rentan terhadap suatu penyakit. Setiap individu memiliki persepsi yang bervariasi tentang kerentanan terhadap suatu penyakit atau kondisi ${ }^{9}$. Bahaya merokok bagi kesehatan yang 
dapat diderita oleh siapapun dapat dijadikan pertimbangan bagi seseorang untuk memutuskan untuk mencoba berhenti merokok atau tidak. Hal yang mendukung teori ini adalah proporsi yang pernah mencoba berhenti dan berhasil berhenti lebih tinggi adalah yang tahu bahwa rokok berbahaya bagi kesehatan.

Penelitian ini sejalan dengan penelitian Pizacani et al (2004) di Oregon Amerika yang menunjukkan bahwa larangan merokok di rumah meningkatkan penghentian kebiasaan merokok. Larangan merokok di seluruh rumah meningkatkan kemungkinan untuk berhenti merokok sebesar 2 kali dibandingkan dengan larangan merokok di sebagian rumah atau tidak ada larangan merokok sama sekali ${ }^{10}$.

Larangan merokok secara total lebih mungkin untuk membuat perokok mengurangi bahkan menghentikan kebiasaannya, dibandingkan dengan jika larangan hanya berlaku di sebagian ruangan saja. larangan total di rumah lebih efektif dalam mengurangi jumlah perokok di kalangan wanita dan orang usia lanjut di atas 65 tahun serta menghentikan kebiasaan merokok pada rumah tanpa anakanak $^{11}$. Pemberlakuan larangan merokok di dalam rumah tangga meningkatkan sikap anti merokok pada remaja dan mengurangi percepatan remaja menjadi perokok coba-coba, karena mereka tinggal dengan orang yang tidak merokok $^{12}$.

Implementasi larangan merokok di rumah di Indonesia, tahun 2010 Quit Tobacco Indonesian (QTI) menginisiasi Program Rumah Bebas Asap Rokok (RBAR) di 4 kampung di Jogjakarta. Gerakan ini merupakan implementasi kebijakan dilarang merokok di tingkat rumah tangga yang berhasil menurunkan jumlah suami dan anggota keluarga lain yang merokok dari 54\% menjadi $37.6 \%$ dan merokok dalam rumah dari $87 \%$ menjadi $37.1 \%$. Program ini merupakan kegiatan pembiasaan merokok di luar rumah dan merupakan kegiatan pengendalian tembakau yang paling bisa diterima. Program RBAR seharusnya merupakan pendukung kebijakan $\mathrm{KTR}^{13}$.

Program RBAR di Jogjakarta, dalam setiap sosialisasi selalu ditekankan bahwa program ini bukan suatu program yang melarang orang untuk merokok atau meminta para perokok untuk berhenti merokok. Program RBAR hanyalah suatu program yang menghimbau para perokok untuk lebih peduli pada kesehatan orang-orang yang dicintainya, dengan cara tidak merokok di dalam rumah. Hal ini dilakukan agar tidak terjadi penolakan di kalangan para perokok. Ketika warga masyarakat setuju untuk melakukan program ini, maka dilakukanlah deklarasi dimana ada 3 kesepakatan yang selalu dicantumkan yaitu: 1) Tidak merokok di dalam rumah, 2) Tidak merokok di pertemuan warga, dan 3) Tidak menyediakan asbak di rumah dan di pertemuan warga.

Isi kesepakatan berbeda pada setiap wilayah, tergantung karakter warga setempat. Beberapa wilayah ada yang menambahkan kesepakatan yang lain sesuai dengan keinginan bersama. Biasanya kesepakatan tersebut adalah: 1) Tidak merokok di depan anak-anak, wanita, dan ibu hamil, 2) Tidak merokok di tempat ibadah, 3) Tidak merokok saat pengajian dan sembahyangan, 4) Tidak menyediakan rokok pada acara kerja bakti, pelayatan, 5) Tidak membuang puntung rokok sembarangan, serta 6) Tidak meminta anak membeli rokok dan menghimbau pemilik warung untuk tidak melayani pembeli rokok usia anak-anak ${ }^{14}$.

Larangan merokok di rumah sebenarnya bukan memaksa perokok untuk berhenti, tetapi lebih kepada melindungi perempuan dan anak, terutama ibu hamil dari dampak buruk rokok para suami, sehingga jumlah perokok pasif berkurang, selain itu larangan merokok di rumah bisa mengurangi remaja yang mencoba untuk merokok.

\section{KESIMPULAN}

Dari $37,3 \%$ responden yang berhasil berhenti merokok, lebih setengahnya $(54,4 \%)$ menerapkan larangan merokok di rumahnya. Larangan merokok di rumah dapat meningkatkan keberhasilan berhenti merokok (OR: 2,0; 95\%CI 1,1-3,4).

\section{SARAN}

Perlunya kerja sama lintas sektor antara pemerintah mulai dari tingkat RT, 
Desa/Kelurahan, Kecamatan sampai Kabupaten dan Propinsi dengan Dinas Kesehatan dan Puskesmas dalam hal penguatan program PHBS dalam tatanan rumah tangga pada indikator tidak merokok dalam rumah serta penerapan larangan merokok di rumah melalui Gerakan RBAR. Perlu dikaji untuk pemberian reward dan punishment agar masyarakat benar-benar melaksanakan aturan ini.

\section{DAFTAR PUSTAKA}

1. Kemenkes. Perilaku Merokok Masyarakat Indonesia berdasarkan Riskesdas 2007 dan 2013. InfoDATIN. Pusat Data dan Informasi Kementerian Kesehatan RI. 2014.

2. WHO. WHO Report on the Global Tobacco Epidemic.WHO. 2008.

3. SEACT. The ASEAN Tobacco Control Report June 2012. Bangkok. 2012.

4. Kemenkes, Laporan Riskesdas 2013. Badan litbangkes. 2013.

5. Kemenkes, Laporan Riskesdas 2010. Badan litbangkes. 2010.

6. Aliansi Pengendalian Tembakau Indonesia (APTI). Peta Jalan Pengendalian Tembakau Indonesia, Perlindungan terhadap Keluarga, Generasi Muda dan Bangsa terhadap Ancaman Bahaya Rokok. Surakarta; Muhammadiyah University Press. 2013.

7. TCSC-IAKMI. Bunga Rampai: Fakta Tembakau, Permasalahannya di Indonesia tahun 2014. Badan Penelitian dan Pengembangan Kesehatan. Kementerian Kesehatan RI. Jakarta. 2014.

8. Bauer, J. E, Hyland, A, Li, Q. Steger, C, Cummings, K. M. A Longitudinal Assessment of the Impact of Smoke-Free Worksite Policies on Tobacco Use.
American Journal of Public Health. 2005; 95(6).

9. Glanz, Karen; Barbara K. Rimer; K. Viswanath. Health behavior and health education: theory, research, and practice. (4th ed.). San Francisco, CA: Jossey-Bass . 2008; 45-51.

10. Pizacani BA, Martin DP. Stark MJ, Koepsell TD, Thompson B, \& Dhier P. A prospective study of Household Smoking Bans and subsequent Cessation Related Behavior: The Role of Stage of Change. Tobacco Control. 2004; 13: 23-8.

11. Zablocki RW, Edland SD, Myers MG, Strong DR, Hofstetter CR, et al. Smoking ban policies and their influence on smoking behaviors among current California smokers: A population-based study. Preventive Medicine. 2014; 59: 73-78.

12. Albers AB, Biener L, Siegel M, Cheng DM, $\&$ Rigotti N. Household Smoking Bans and Adolescent Antismoking Attitudes and Smoking Initiation: Findings From Longitudinal Study of a Massachusetts youth cohort. Am. J. of Pub. Health. 2008; 98(10): 1886-93.

13. Padmawati, Retna Siwi dkk. Gerakan Rumah Bebas Asap Rokok dan Implementasi Penerapan Kebijakan Kawasan Tanpa Rokok di Yogjakarta. Dibawakan pada Forum Nasional II: Jaringan Kebijakan Kesehatan Indonesia. Makassar. 2011.

14. Rahaju, J. R, Pujiastuti, E. Istiyani, T, Prabandari, Y. S, Padmawati, R. S. Program Rumah Bebas Asap Rokok di Kota Yogyakarta, Quit Tobacco Indonesia. Dibawakan pada $2^{\text {nd }}$ ICTOH Tobacco Control: Save Young Generation, Save the Nation. Jakarta. 2015. 